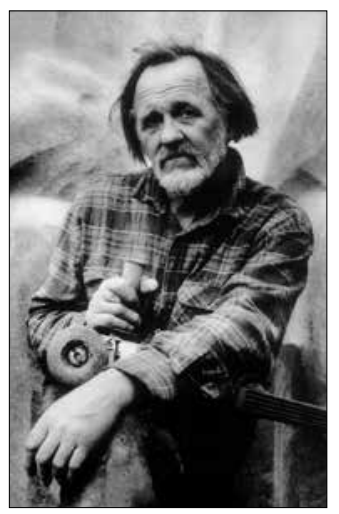

Tapyba

In memoriam

Skulptūra

https://doi.org/10.24101/logos.2019.58

Painting

Gauta 20190831

Sculpture

ANTANAS

KMIELIAUSKAS

\title{
DAILININKAS ANTANAS KMIELIAUSKAS
}

Antanas Kmieliauskas (1932-2019) - vienas universaliausiu šiuolaikinių lietuviu dailininku, tapytojas, monumentaliosios dailès kūrèjas, skulptorius, grafikas, dailès pedagogas, Nacionalinès kultūros ir meno premijos laureatas. Gimė 1932 m. Olendernèje (Alytaus r.), 1951 m. aukso medaliu baigè Kauno vidurinę dailès mokyklą, 1951-1957 m. tęsė studijas Lietuvos dailès instituto Tapybos katedroje. 1962-1977 m. dėstė Vilniaus vaikų dailès mokykloje, nuo 1977 m. dèstè Vilniaus dailès akademijoje (profesorius nuo 1994 m.). Nuo 1960 m. dalyvavo parodose. 1975 m. tapo Lietuvos dailininkų sąjungos nariu. Didžioji jo kūrybos dalis, ypač religinė dailè, ilgą laiką buvo nepelnytai ignoruojama.

Nutapė portretų, peizažų, kompozicijų, freskų, sukūrẻ dekoratyvių skulptūrų, skulptūrinių portretų, apie 30 antkapinių paminklų, daugiau kaip 320 ekslibrių (Tarptautinių ekslibrio konkursų San Vito (Italija) aukso medalis ir Bledo (Serbija ir Juodkalnija) pirmoji premija - abu 1974 m.), estampu (daugiausia peizažai, Vilniaus architektūros paminklai). Freskoms būdinga netikèti rakursai, prislopintas koloritas, skulptūroms - apibendrintos formos, raiškus siluetas. 1994 m. už Rainių kančių koplyčios freskas apdovanotas Nacionaline premija.

Prof. dr. Antanas Andrijauskas

\section{Artist Antanas Kmieliauskas}

Antanas Kmieliauskas (1932-2019) is one of the most versatile contemporary Lithuanian artists, painters, monumental art creators, sculptors, graphic artists, art educators, and winners of the National Culture and Art Prize. He was born in 1932 in Olenderne (Alytus district). In 1951, he graduated from Kaunas Secondary School of Fine Arts. From 1951 till 1957, he studied at the Painting Department of the Lithuanian Art 
Institute. From 1962 till 1977, he lectured at Vilnius Children's Art School. Since 1977 Kmieliauskas lectured at Vilnius Academy of Arts (Professor since 1994). Since 1960, he participated in exhibitions. In 1975, he became a member of the Lithuanian Artists' Union. Most of his works, especially with religious content, had been unduly ignored.

Kmieliauskas painted portraits, landscapes, compositions, murals, created ornamental sculptures, sculptural portraits, about 30 tombstones, and more than 320 ex-librises. In 1974, he awarded by gold medal in San Vito (Italy) ex-librises competition and first prize in Bled (Serbia and Montenegro). His prints are mainly dedicated to landscapes and architectural monuments of Vilnius. To his murals unexpected angles and muted colors are typical; to sculptures - generalized shapes and a crisp silhouettes. In 1994, he got the National Prize for the frescoes of Rainiai Martyrdom Chapel.

Professor dr. Antanas Andrijauskas

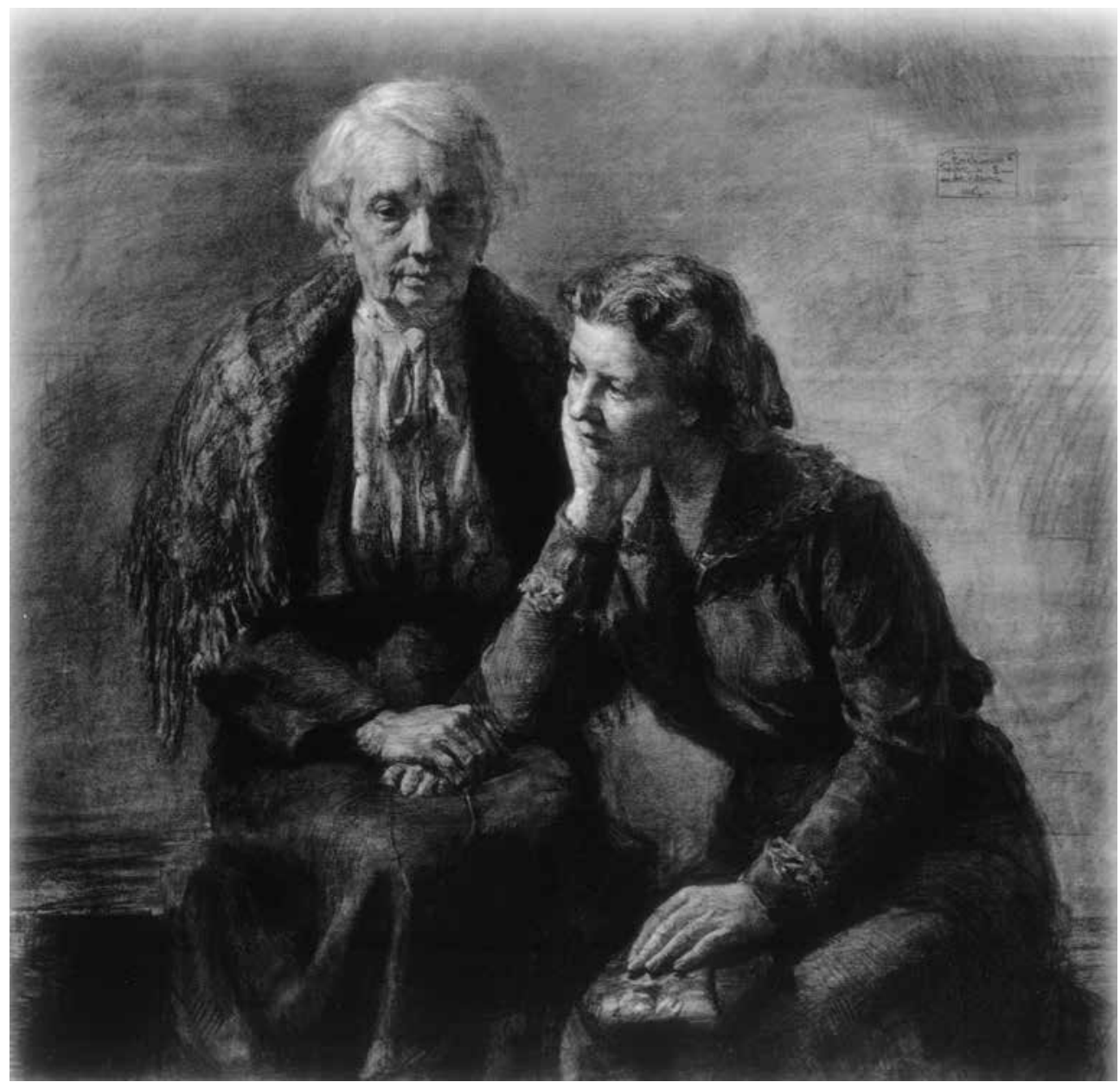

Antanas KMIELIAUSKAS. Dviejų žmonių kompozicija. 1955 


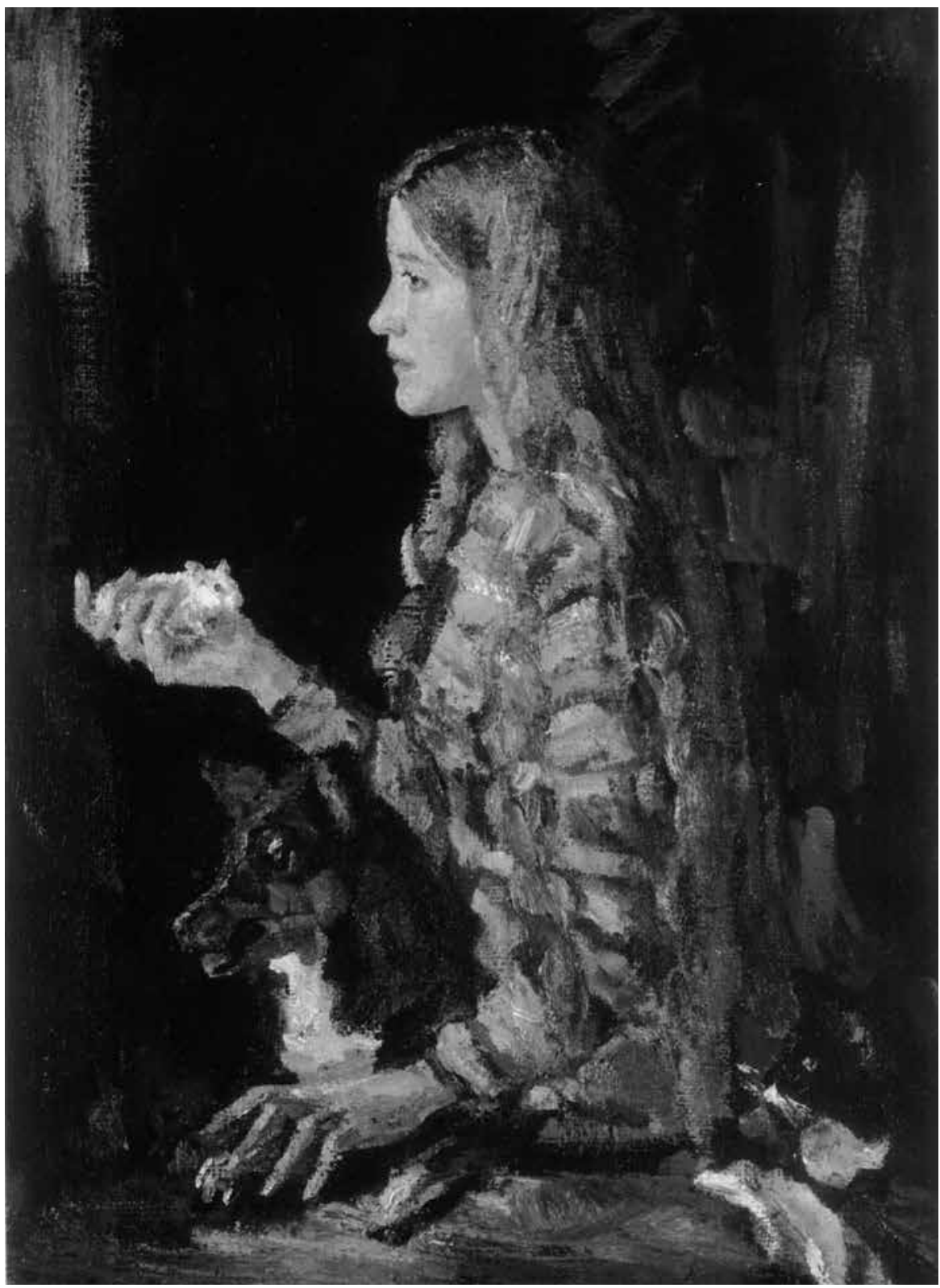

Antanas KMIELIAUSKAS. Ramunė su gyvūnèliais. 1966. Drobè, aliejus. $98 \times 70$ 


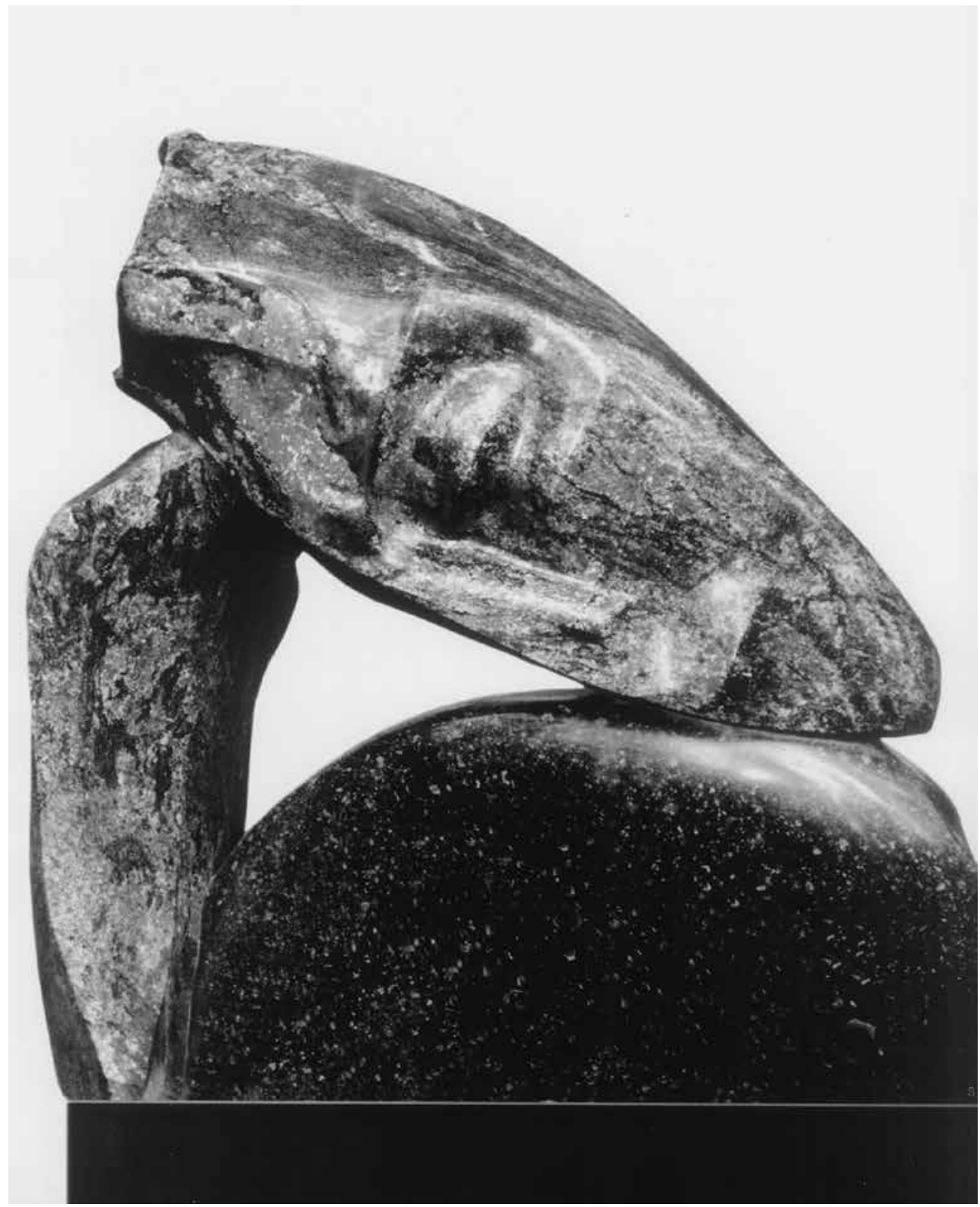

Antanas KMIELIAUSKAS. A. Lapinskienès antkapinis paminklas. 1975. Granitas. $124 \times 120 \times 40$.

Vilniaus Rasų kapinès 


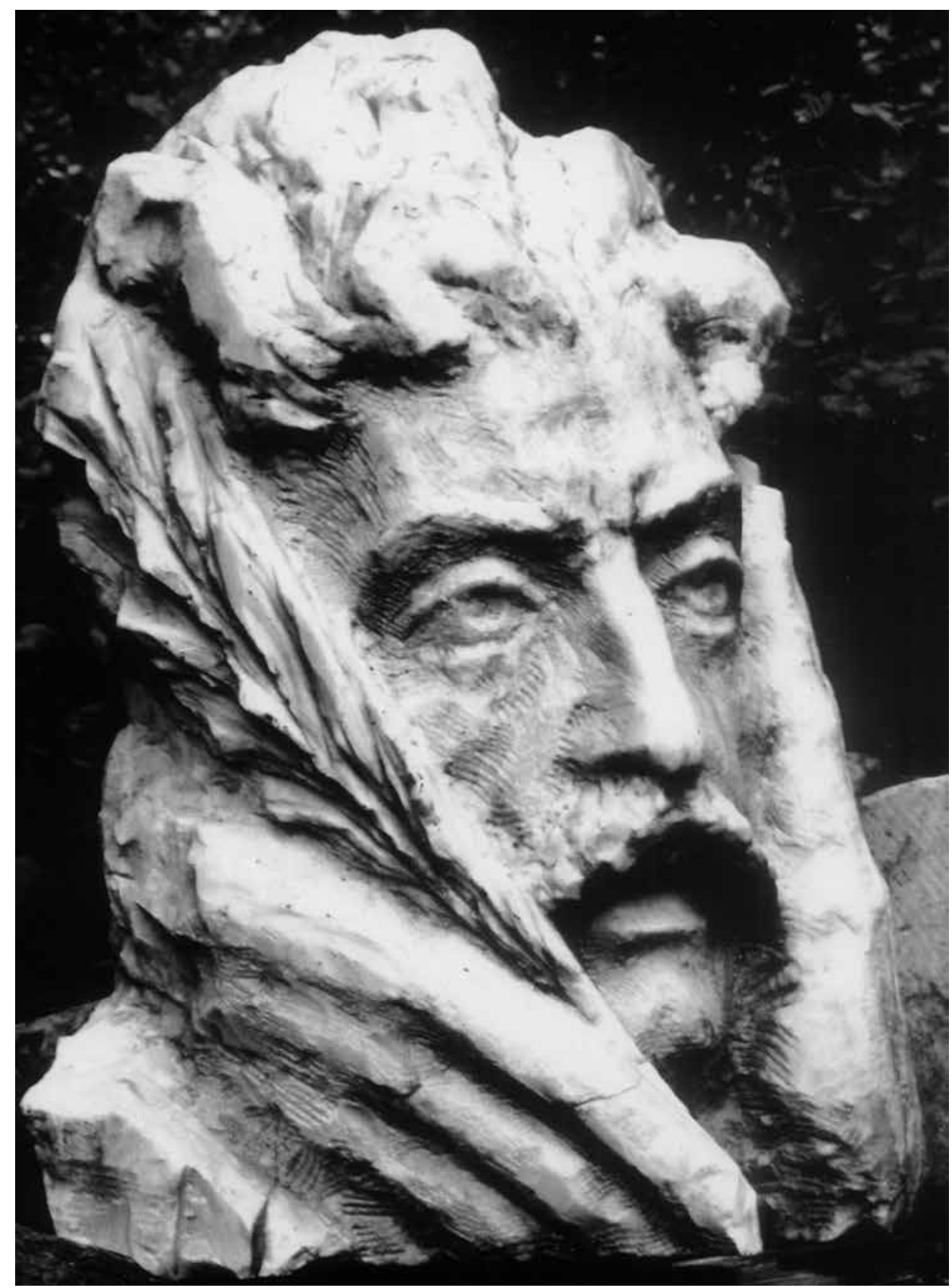

Antanas KMIELIAUSKAS. Ikvejpimas. M. K. Čiurlionio portretas. 1998. Marmuras. $80 \times 45 \times 40$. Autoriaus nuosavybė 


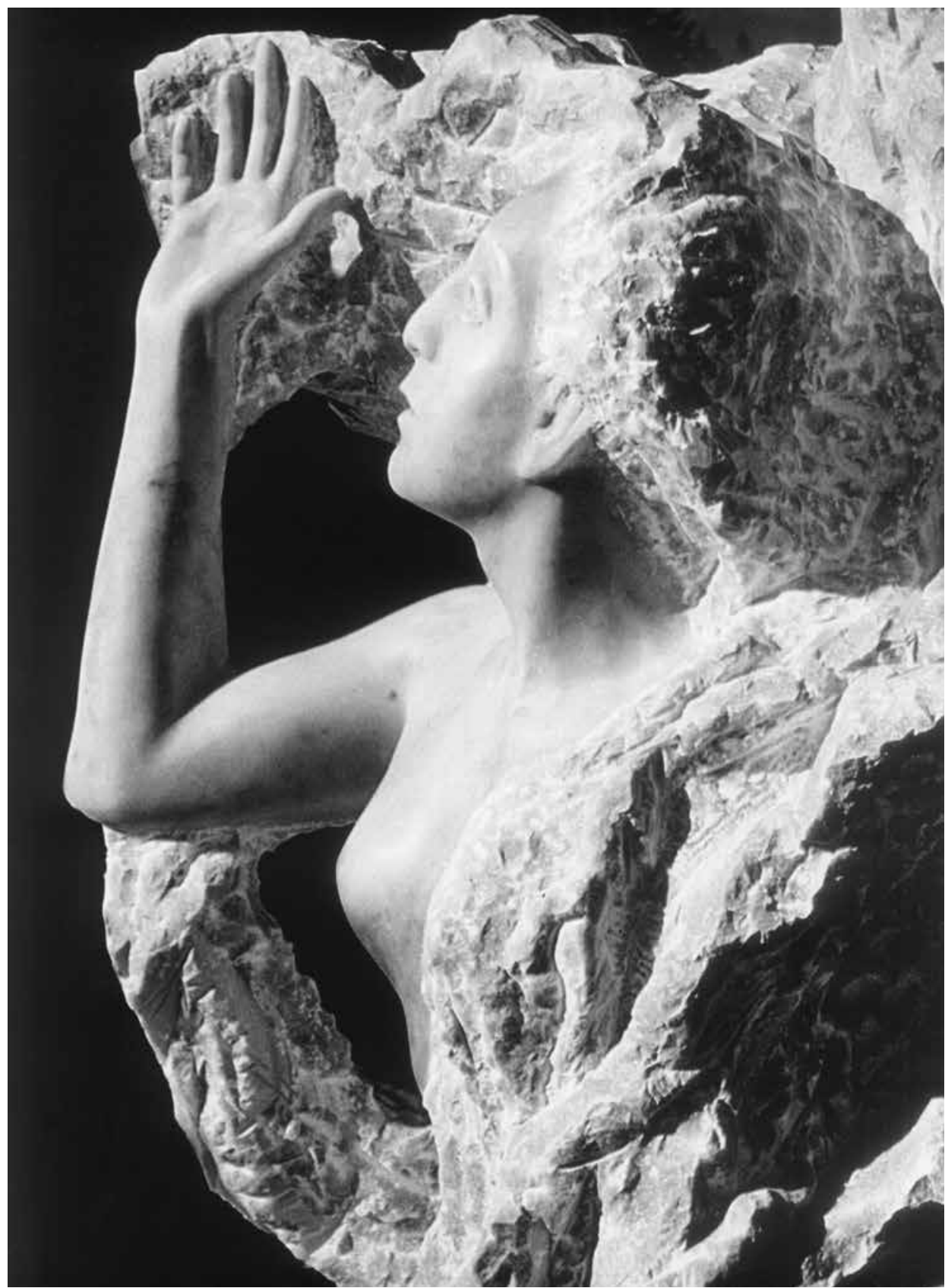

Antanas KMIELIAUSKAS. Aretūza, virstanti upele. Fontano skulptūros fragmentas iš ciklo „Metamorfozės". 1994-1995. Marmuras. Gamberalè, Italija 